
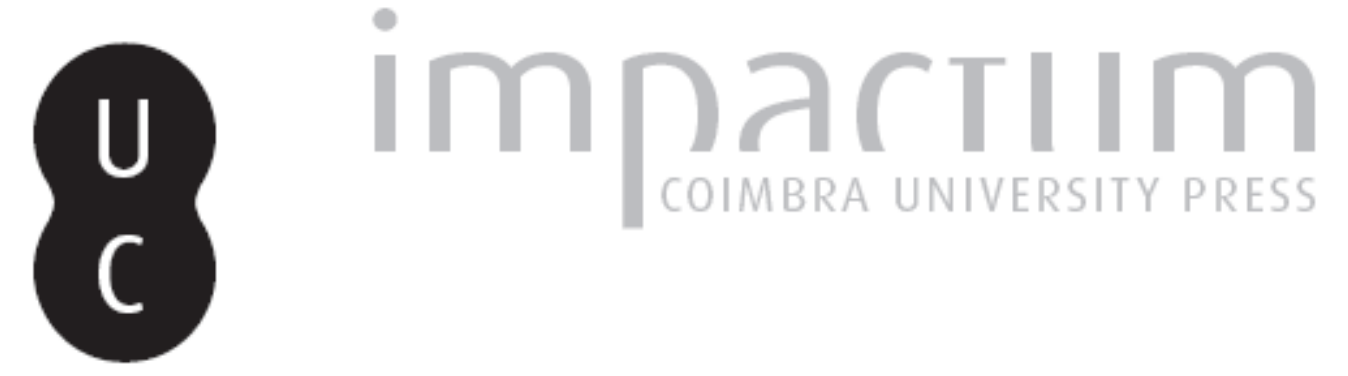

\title{
[Recensão a] SEXTO EMPÍRICO (2013). CONTRA OS RETÓRICOS. INTRODUÇÃO, TRADUÇÃO E NOTAS DE RODRIGO BRITO E RAFAEL HUGUENIN
}

\author{
Autor(es): $\quad$ Dinucci, Aldo \\ Publicado por: Annablume Clássica; Imprensa da Universidade de Coimbra \\ URL \\ persistente: \\ URl:http://hdl.handle.net/10316.2/37016 \\ DOI: \\ DOI:http://dx.doi.org/10.14195/1984-249X_15_15 \\ Accessed : $\quad$ 26-Apr-2023 16:19:16
}

A navegação consulta e descarregamento dos títulos inseridos nas Bibliotecas Digitais UC Digitalis, UC Pombalina e UC Impactum, pressupõem a aceitação plena e sem reservas dos Termos e Condições de Uso destas Bibliotecas Digitais, disponíveis em https://digitalis.uc.pt/pt-pt/termos.

Conforme exposto nos referidos Termos e Condições de Uso, o descarregamento de títulos de acesso restrito requer uma licença válida de autorização devendo o utilizador aceder ao(s) documento(s) a partir de um endereço de IP da instituição detentora da supramencionada licença.

Ao utilizador é apenas permitido o descarregamento para uso pessoal, pelo que o emprego do(s) título(s) descarregado(s) para outro fim, designadamente comercial, carece de autorização do respetivo autor ou editor da obra.

Na medida em que todas as obras da UC Digitalis se encontram protegidas pelo Código do Direito de Autor e Direitos Conexos e demais legislação aplicável, toda a cópia, parcial ou total, deste documento, nos casos em que é legalmente admitida, deverá conter ou fazer-se acompanhar por este aviso.

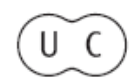




\section{5}

jul/dez

2015

issn 2179-4960

e-issn 1984-249-X
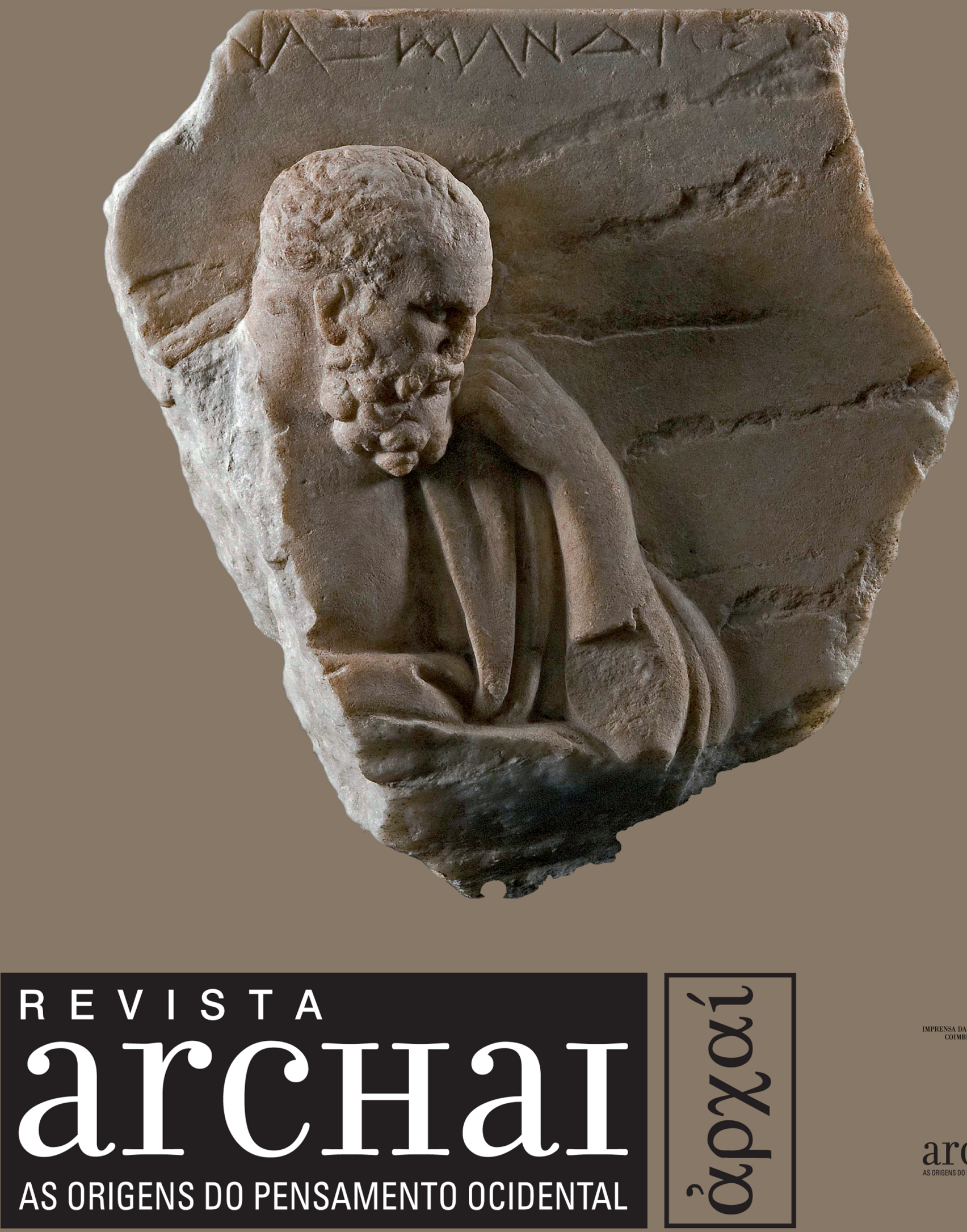

ARCHAI JOURNAL: ON THE ORIGINS OF WESTERN THOUGHT

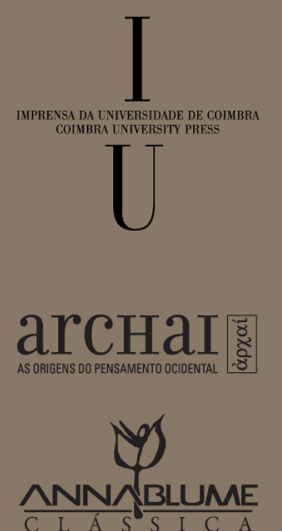




\section{SEXTO EMPÍRICO (2013). CONTRA OS RETÓRICOS. INTRODUÇÃO, TRADUÇÃO E NOTAS DE RODRIGO BRITO E RAFAEL HUGUENIN. MARÍLIA, UNESP}

DINUCCI, A. (2015). Resenha. SEXTO EMPÍRICO (2013). Contra os Retóricos. Introdução, Tradução e notas de Rodrigo Brito e Rafael Huguenin. Marília, UNESP.

Archai, n. 15, jul. - dez., p. 153-155

DOI: http://dx.doi.org/10.14195/1984-249X_15_15
* Professor associado da Universidade Federal de Sergipe - Sergipe, Brasil aldodinucci@yahoo.com.br

1 "The safest general characterization of the European philosophical tradition is that it consists of a series of footnotes to Plato" (WHITEHEAD, A. N. (1929). Process and Reality. An Essay in Cosmology.

Gifford Lectures Delivered in

the University of Edinburgh During the Session 1927-1928. Cambridge, Cambridge University Press, p. 39).

2 VON ARNIM, H. (2005). Stoicorum Veterum Fragmenta Volume 1: Zeno or Zenonis Discipuli [1903]. Berlim. De Gruyter.

3 LONG, A. A. \& SEDLEY, D. N. (1987). Hellenistic Philosophers (volumes 1 \& 2). Cambridge, Cambridge University Press.

4 DUDLEY. D. R (1937). A history of cynicism. Londres, Mithuen \& co.

5 LUKASIEWICZ, J. (1970). On the History of the Logic of Proposition [1934]. IN: Jan Lukasiewicz Selected Works. Amsterdam, North-Holland Pub. Co.

6 MATES, B. (1961), Stoic Logic. Berkeley-Los Angeles, University of California Press.

7 Refiro-me aqui particularmente ao impressionante trabalho de 1966: Galen and the syllogism (Pittsburgh, University of Pittsburgh Press), no qual Rescher comenta um tratado de Galeno sobre lógica que nos chegou em árabe.

\section{Aldo Dinucci}

A té certa altura do século XX compreendiase, nos meios de pesquisadores de filosofia antiga, o dito de Whitehead segundo o qual tudo o que fora escrito depois de Platão serviria tão somente como notas de rodapé aos diálogos do ateniense ${ }^{1}$ como uma confirmação da suposta inferioridade e redundância das filosofias helenísticas em relação àquelas de Platão e Aristóteles. Entretanto, tal visão logo se viu superada pelo trabalho acadêmico de eminentes pesquisadores que reuniram os fragmentos das obras dos filósofos helenistas e começaram a estudá-los. Von Arnim, no princípio do século $X X$, já coletara os fragmentos dos antigos estoicos $^{2}$. Décadas depois, Anthony Long e David Sedley completaram uma importante obra ${ }^{3}$ na qual selecionaram e comentaram fragmentos dos estoicos, dos céticos e dos epicuristas. Filósofos destacados como Dudley ${ }^{4}$ pesquisaram o que nos chegou dos cínicos. Lukasievicz ${ }^{5}$ e Benson Mates ${ }^{6}$, notáveis lógicos contemporâneos, debruçaram-se sobre a lógica estoica. E a lista não parou mais de aumentar. Hoje, filósofos de vulto, como Suzanne Bobzien, Jonathan Barnes, Julia Annas e Nicholas Rescher $^{7}$ dedicam-se ao estudo dos filósofos helenistas. A tal ponto valorizou-se o estudo destes filósofos que, entre norte-americanos e europeus, não se concebe mais que um pesquisador de filosofia 
antiga ignore ou não dedique parte de seu tempo ao estudo dos helenistas.

0 filósofo francês Pierre Hadot, também responsável pela valorização do estudo dos filósofos helenistas, foi um dos primeiros a enfatizar o caráter existencial dessas filosofias, que se traduz pela complementaridade entre teoria e prática. Essa ligação da filosofia com a ação, da filosofia eleita como escolha de vida, é o diferencial dessas filosofias, tanto em relação àquelas de Platão e de Aristóteles, quanto no que tange à filosofia moderna e contemporânea que, herdeiras do medievo, trazem consigo a ferida da separação medieval entre a filosofia e a prática filosófica - melhor ainda: da extirpação desta última em nome de uma moralidade cristã fundada no dogma teológico ${ }^{8}$.

0 ceticismo é um dos quatro pilares do helenismo filosófico, sendo os outros o estoicismo, o cinismo e o epicurismo. Sua aposta é alta: a busca da imperturbabilidade através da suspensão de juízo e da superação dos dogmatismos filosóficos. No Brasil, o ceticismo antigo tem sido pesquisado por grandes filósofos do cenário nacional, tais como Danilo Marcondes Filho e Luiz Bicca, só para citar dois nomes que nos vêm imediatamente à mente. Entretanto, faltavam as traduções dos textos primários, em especial a tradução das obras de Sexto Empírico, médico e filósofo que viveu provavelmente entre 160 e 210 d.C. e que é um dos expoentes do ceticismo antigo, ao lado de Pirro de Élis (360-270 a.C.). Essa lacuna começou a ser preenchida, em 2013, pelos jovens pesquisadores Rodrigo Pinto de Brito e Rafael Huguenin (ambos graduados em filosofia pela UERJ e mestres e doutores em filosofia pela PUC-RJ) com a publicação pela UNESP da tradução bilíngue e anotada de Contra os Retóricos, de Sexto Empírico.

Rafael e Rodrigo fazem ambos parte do Viva Vox, grupo de pesquisa da Universidade Federal de Sergipe que conta com a maior biblioteca especializada em filosofia helenista da América Latina, biblioteca que vem se constituindo com o apoio de sucessivos editais do CNPq. Além de editor-júnior da revista de filosofia Prometeus ${ }^{9}$, Rodrigo Pinto de Brito é o responsável, junto com Cesar Kiraly, doutor em filosofia, professor da UFF e autor de Ceticismo e Política (São Paulo: Giz editorial, 2012), pela organização dos Colóquios sobre Ceticismo, evento que ocorre desde 2012 no Rio de Janeiro.

Dos tratados de Sexto, três nos chegaram: Esboços de Pirronismo e dois outros (con)fundidos na obra intitulada Adversus Mathematicos. Cada um dos seis primeiros livros dessa obra recebe um nome diferente: Livro I - Contra os Gramáticos; Livro II Contra os Retóricos; Livro III - Contra os Geômetras; Livro IV - Contra os Aritméticos; Livro V - Contra os Astrólogos; Livro VI - Contra os Músicos. Os livros VII, VIII, IX, X e XI perfazem outra obra, que nos chegou incompleta, sendo os livros VII e VIII intitulados Contra os Lógicos; os livros IX e X, Contra os Físicos; e o Livro XI, Contra os Éticos.

Contra os retóricos, a obra comentada, traduzida e anotada pela dupla de jovens filósofos cariocas, corresponde ao livro II de Adversus Mathematicos. Em Contra os Retóricos, Sexto busca demonstrar a impossibilidade de ensinar a retórica e negar que a retórica seja uma arte (techne). Começando pela constatação da multiplicidade de concepções coexistentes de techne, Sexto conclui pela falta de consistência da noção. 0 próximo passo do filósofo é a tentativa de provar que é impossível definir tal techne, através do exame da definição platônica, aristotélica e acadêmica de retórica. Sexto volta-se então para a concepção estoica, buscando refutá-la ao final do opúsculo.

A obra de Sexto, essencial para a compreensão do ceticismo antigo, é riquíssima como fonte de fragmentos de outras correntes filosóficas da Antiguidade. Sexto é a principal fonte para conhecermos a lógica estoica, sendo um dos poucos comentadores antigos que têm real compreensão do escopo de tal lógica (Diógenes Laércio, nossa segunda mais importante referência no assunto, nada faz senão citar verbatim o manual de lógica de Díocles de Magnésia).

A tradução comentada e anotada de Contra os Retóricos é realizada com esmero. As notas são abundantes e relevantes, constituindo-se como ferramenta de pesquisa da mais alta qualidade. Lamenta-se, entretanto, que a EDUNESP não tenha ainda disponibilizado graciosamente o pdf da obra, de modo a difundi-la como se deve. Que se tome como exemplo, para isso, os Classica Digitalia ${ }^{10}$, da

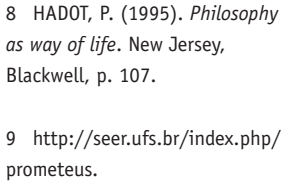


Universidade de Coimbra, que combinam edições físicas excelentes com a divulgação gratuita em formato digital.

Contra os Retóricos pode ser adquirido diretamente pelo site da editora EDUNESP, no link: http://www.editoraunesp.com.br/catalogo-detalhe. asp?ctl_id=1486. Estão todos convidados então para, junto com Sexto, buscarem a imperturbabilidade através da razão crítica e da suspensão de juízo. Dos mesmos pesquisadores teremos, neste ano de 2015, a publicação de Contra os Gramáticos, obra que se encontra já no prelo, também pela EDUNESP.

Submetido em Dezembro de 2014 e aprovado em Fevereiro de 2015. 